\title{
Theoretical Framework of Fair Distribution of Affordable Housing in China
}

\author{
Tao Zhang \\ Faculty of Human Ecology, University Putra Malaysia \\ PO Address 43400, Human Ecology UPM Serdang, Selangor Darul Ehsan, Malaysia \\ E-mail: zhangtaomike@yahoo.com.cn \\ Ahmad Hariza B Hashim \\ Faculty of Human Ecology, University Putra Malaysia \\ PO Address 43400, Human Ecology UPM Serdang, Selangor Darul Ehsan, Malaysia \\ E-mail: ahariza@putra.upm.edu.my
}

Received: April 12, $2011 \quad$ Accepted: May 1,2011 doi:10.5539/ass.v7n9p175

\begin{abstract}
Urbanization and industrialization in China result in dramatic growth of population in urban areas. The housing price rises so high that low-income people living in urban cannot afford to buy their own houses. In order to alleviate their housing plight, affordable housing has been built in mainland China. However, unfair distribution of affordable housing failed to accomplish the goal of this program. The paper firstly introduces the current situation and problem of affordable housing distribution. It then discusses the rationale of Theory of Justice from John Rawl, and puts forward a systematic legal framework, which consists of affordable housing legislation, enforcement, judiciary and sanction, to safeguard the justice of affordable housing distribution.
\end{abstract}

Keywords: Affordable housing, Distribution, Justice, Law

\section{Introduction}

Affordable housing in its essence is purported to provide welfare to the vulnerable strata. To some extent, it manifests the sense of responsibility of the government to accomplish the distributive justice so as to seek the social justice. Therefore, how to differentiate the targeted eligible applicants from the other urban residents is the prerequisite for the existence of affordable housing policy and also represents its disposition of core value to preserve basic right to housing of vulnerable strata and equality of the society. Meanwhile, Chinese government formulated a series of regulations and brought them into effect to safeguard the fair distribution of these affordable housing to the least advantaged people to solve their housing plight.

Research on the affordable housing distribution from legal perspective is sparse in academic literature. Excessive attention has been paid to the affordable housing policy, planning, financing and infrastructure, but very little touches on the process and the outcome of affordable housing delivery. Not only is regulation one of the crucial components in affordable housing industry, which exerts a regulatory guidance on every aspect of the industry, but also its first priority is to safeguard the delivery of the affordable housing to the targeted group which is the last linkage of the affordable housing industry and also the eventual distributive justice of affordable housing industry.

Law is the most powerful and binding means to safeguard the implementation of the affordable housing policy and is considered as a sharp sword to accomplish the distributive justice in allocation of affordable housing. It is rational for everyone to believe that the affordable housing has been distributed to the applicants who meet the criteria set by law.

However, in reality, due to high price of house and speculation, many people are attracted by the affordable housing for the prospective interests. And, there are many cases of unfair distribution of affordable housing especially to those who are not eligible to access to it. The true situation has been unraveled through public medias across the country, like Wu Han racketing case of affordable housing (Legal Daily, 2009). Based on the 
illustrations and exploration of introduction and background, the research question is how to perform fair distribution of affordable housing in China? Therefore, the objective of this study is to explore a rational scenario of fair distribution of affordable housing in China.

\section{Background}

China has undergone a rapid urbanization since the 1980s. By the end of year of 2009, the total population reached 1.334 billion with 712 million (53.4\%) and 622 million (46.6\%) living in rural and urban regions respectively. The United Nations has projected that population of China will arrive at about an equal number of those residing in the rural and urban areas by 2015 (State of World of Population, 2007). Although urbanization and industrialization in China have contributed to a great development of its social civilization and economic prosperity, poor urban residents, a new social stratum has gradually formed. Dorothy (2005) defined this new social stratum as urban underclass which consists of three groups in the cities: the "laid-off" workers, the labourers from the rural areas who move into the cities in search of work, and the growing number of poor people.

Lands are limited resources, especially in the city. Demands from housing industry means more lands are needed to build house. However, the continuous increase in demand with limited supply of housing could trigger the housing price to go up. The rapid process of urbanization and industrialization has brought about the densely populated cities as geographically and socially aggregate areas full of economic tendency. All these stimulate the demands for housing in cities, especially big cities, and gives rise to the implicit shortage of housing supply and the price hike in housing.

It is expected that the life of urban underclass will be under straitened circumstances due to rocket high-sky price of housing. With the increase in price of housing, it means they may not afford to buy a house and are forced to live in slums with poor environment and conditions. The upbeat of housing price are so conspicuous and immense that it no longer become affordable for first-time home buyer. For the urban underclass, it even becomes more difficult for them access to the housing market. In fact, skyrocketing housing price is also imposing stress on the middle class, and not just to the low-income strata.

In addition, as wealth gap is widening and the housing price increases tremendously in China. Nevertheless the living standard of urban underclass maintains relatively low level. The income of the top 10 percent of the richest Chinese was 23 times that of the bottom 10 percent of in the country in 2007, as compared with the statistics in 1998, when the gap was only 7.3 times (Chen, 2009). Therefore, buying a house is becoming more difficult than ever for those urban poor strata. Consequently, the poor are forced to settle in damp and congested substandard housing where plagues, crimes and relegation of social regulations and morality will be incidental with. All these negative issues are undermining the social economic development and political stability.

In order to alleviate the severity of living conditions of residents in urban areas, Chinese government has established a security housing system to solve the housing issues, which consist of affordable housing system and low rent system. Each system targets different group of people. This study mainly focuses on the affordable housing system (See Figure 1).

Affordable housing system in China started in 1998 (Yi, 2008). The central government and local governments formulated a body of affordable regulations to safeguard the rights and interests and to improve the living conditions of urban poor people (See Table 1). According to the affordable housing regulations, affordable housing program is granted some preferencial policies of tax and relevent fees and the allocation of the right to use state-owned land is administered without land grants (Affordable Housing Regulations, 2007). So, the price of affordable housing is cheaper than that of the housing supplied by market. To some extent, it helped to solve a number of people's housing plight. In fact, affordable housing was built across the whole nation in China (See Table 2).

\section{Affordable Housing In China}

In view of the different historic and national context, meaning and usage of the concept like affordable housing is subject to distinctive perceptions. The term 'affordability'is concerned with the annual price or a rent paid for consumption upon housing (Haffner \& Boumeester, 2010). Gabriel et al. (2005) defines affordable housing as lower cost housing than prevailing market price to meet up with the minimum affordability requirements of low-income people and the affordability can be measured based on various indicators. However, Milligan et al. (2004), he emphasizes that affordable housing should be built for the poor or low-income social stratum by non-governmental not-for-profit providers and affordable housing could be financed through various ways to provide low price housing. According to Affordable Housing Management Mehods (2007), it suggests that 
affordable housing should be defined as a kind of security housing supported by government preferential policies, which is restricted from the perspective of areas and sale price to be provided to the urban low-income people with housing difficulty and is built in compliance with normal construction standard.

In China, the central government and local governments formulated a body of regulations to safeguard the rights and interests of urban poor people's living conditions. According to the affordable housing regulations, affordable housing program is granted preferencial policies of tax and relevent fees, and the allocation of the right to use state-owned land is administered without land grants (Affordable Housing Management Mehods, 2007). In addition, government sets the construction standards and qualification criteria. Only households which meet the requirements can apply to buy or rent such housing. In fact, affordable housing is policy-based, security-type commercial housing. The target people are those local residents with registered permanent residential permission (HuKou) having serious housing problems including those without housing of their own or with their current housing space below the standards set by the local government. Besides, their family incomes must meet the minimum income standard set by the local government.

Government adheres to the low-profit advocacy for affordable housing development. The profit rate for affordable housing developers are required not to outnumber 3 per cent. Therefore, these housings are provided at prices which are 40 per cent less than market offer. Only after a stipulated period of time following the purchase of such housing may the owner sell it at the market, and a portion of the sale price therefrom must be kicked over to the government in form of tax. The purchase of this kind of housing must be subject to application, examination and public announcement, thus emphasizing public transparency and strict supervision and administration.

\section{Theoretical Framework of Fair Distribution of Affordable Housing}

Interpreting justice is never a easy task, as Bodenheimer (1981) suggests "Justice has a Protean face, capable of change, readily assuming different shapes, and endowed with highly variable features. When we look deeply into this face, trying to unravel the secrets hidden behind its outward appearance, bewilderment is apt to befall us." A well-known definition of justice, set forth in Justinian's Corpus Iuris Civilis and attributed to the Roman jurist Ulpian, reads as follows: "Justice is the constant and perpetual will to render to everyone that to which he is entitled." At even earlier time of Roman cilization, Cicero had depicted justice as "the disposition of the human mind to render to everyone his due (Cicero, 1951)." The noteworthy aspect is the subjectivity of justice in these two definitions. Bodenheimer (1981) points out that justice is perceived as a kind attitude of the people's faith, a certain voluntariness to pursue fairness and a certain inclination to confer cognizance to the assertions and concerns of others; Without this attitude and willingness, justice cannot develop and prosper in society; Nonetheless, it is noteworthy that the mere enlightenment of a mental loyalty to fairness and concerns for others is not, in and by itself, necessary to cause the success of the reign of justice; The good faith to commit justice must be carried out by feasible resolutions like policies and laws designed to accomplish the goals of a just society.

However, Aristotle (1934) points out a different approach. He believes that justice shall be done based on the equality. Further, he categorizes justice into distributive justice and corrective justice. In his oppinion, distributive justice is primarily concerned with the demand of equit allocation of the wealth of the world in compliance with the principle of proportionate equality. He also sets forth that the meaning of distributive justice consist of the assignment of rights, power, duties, and burdens to the members of a society or group. He emphasizes that equal things ought to be alloted to equal persons and vice versa. Even for this, he advocates a measurement of equality which is merit and civic excellence. If one person deserves two times as much as the other, his ought to be twice as large (Aristotle, 1934).

Aristotle distinguishes distributive justice from corrective justice. He states that if the norm of distributive justice has been defied, the corrective justice shall come into play (Rackham, 1934). This means that rights (including personal rights, property rights and so on) of one member in civil society has been violated by others, corrective justice shall return the property which he used to possess or make restitution for his loss. Actually, its function is to correct a wrongdoing or dispossess an unjustified gain of the offender. Court or other bodies conferred with judicial powers are the main channels to aquire the remedy according to the norms of corrective justice. And its primary domains of application are civil activities and criminal offences (Bodenheimer, 1981).

The above interpretations given by Aristotle are very broad. Every time when particular case occurs, it has been found quite hard to seek the concrete guidance to probe into the essence of the issue. Actually, "The concept of justice includes norms and principles which a particular political and social system regards as just, whether or not these norms and principles have found express recognition in a formalized sources of law" (Pound, 1923). 
However, based on the research context, John Rawls' A Theory of Justice comes closest to including the elements of justice that are identified as policy goals, implementation strategies and evaluation criteria.

A Theory of Justice developed by John Rawls (1971) has a different perspective while interpreting the meaning of justice. His theory comprises two pivotal principles:

(1). An equal right is endowed to every person in the society and the core value of equal right is to embody the whole system of equal basic liberties which are adaptable with a similar system of liberty for all.

(2). Inequalities from social and economic dimensions are to be organized. So, to the benefit of the least advantaged, compatible with the just savings principle, and associate to offices and positions available to all under the conditions of equal opportunity needs to be done.

These two principles from A Theory of Justice primarily apply, as Rawls (1971) emphasized, to the fundamental framework of society. They are designed to administer the consignment of rights and liability, and to regulate the allocation of social and economic benefits. The basic liberty of citizens roughly includes political liberty; freedom of the right to own personal property; and freedom from arbitrary arrest. All aforesaid components of liberties are claimed by the first principle, since citizens in civil society ought to have same basic rights. The second principle applies to the allocation of wealth. Its approach is to arrange some organizations with their respective authority and responsibility, or chains of command. While the allocation is not necessarily to be equal, it must take care of everyone's advantage. Simultaneously, positions of authority and offices of command must be open to all so that every citizen can take advantage.

Furthermore, Rawls (1971) advocates a four-stage sequence which demonstrates how the two principles for institutions are to be applied.

(1). Agreement on the two principles of justice and a principle of just savings.

(2). Crafting a Consititution to realize the two principles

(3). Crafting specific laws and policies that realize the two principles within the constitutional framework

(4). Judges and administrators to apply the previously-agreed laws and policies to particular cases.

Based on the above illustration, the theoretical framework involves fundamental principles of justice and the means for their application. The two principles are the basis underpinning the framework of justice. The theory elaborates the meaning of justice as fairness and devises the target of justice for the benefits of the least advantaged people. Furthermore, four stage sequence constructs a framework and sets forth the vital elements to achieve the justice.

In Rawl's theory, it identified Four Stage Sequence as an instrument to fulfil the goals of the its two principles. In fact, the core value embodied in Four Stage Sequence was the emphasis on the advocacy of legal function in the achievement of two principles. But, it was not concrete enough to illustrate the significance of law in the context. Hereby, it is necessary to resort to another concept to demonstrate the profile of law. In a common sense, legal strategy embodies a conceptual framework known as legal operational system which consists of legislation, law enforcement, judiciary and sanction as showed in Figure 2. Therefore, based on a Theory of Justice and legal operational system, the theoretical framework can be showed in Figure 3.

\section{Conceptual Framework of Affordable Housing Distribution in China}

Based on the literature review and theoretical framework, law is recognized as an effective instrument to achieve the fair distribution of affordable housing. To attain this end, each element within the legal operational system need to function properly including affordable housing legislation, affordable housing law enforcement, affordable housing judiciary remedy and sanction on wrongdoings.

\subsection{Affordable Housing Legislation}

Concerning the affordable housing legislation, law in its nature should embody validity and efficacy. The validity of affordable housing law touches on the justice of the legislative content and goals. In the other words, affordable housing ought to be distributed to eligible low-income people. This is the purport and the goal of the affordable housing legislation. The concrete legislative contents are to safeguard the realization of the affordable housing legislative goal. Surely, only if there is a just affordable housing legislative purport and goal, it is far from enough to guarantee the the attainment of fair distribution of affordable housing to eligible low-income people.

Therefore, how effective the specific contents of the affordable housing regulation plays a significant role in safeguarding the eventual fair distribution of the affordable housing. Efficacy should involves not only the 
complete and detailed regulatory articles, but it should include the rational and feasible application procedure for prospective applicant and administrative procedure for law enforcement officers as well.

\subsection{Affordable Housing Law Enforcement}

To perform the fair distribution of affordable housing, the implementation of the affordable housing legislation generally goes through four steps including acceptance, verification, supervision and administration.

\subsubsection{Acceptance}

The affordable housing applicants should submit all the application documents at the beginning including application form, family income certificate, family housing certificate, identify card of each family member and certificate of registered permanent residence, and other documents as required. Then, the authority accepts all the documents.

\subsubsection{Verification}

In fact, this process includes another two steps which are preliminary examination and review. After accepting the application documents from the applicants, community committee and district office will conduct the preliminary examination. They will check if the application documents are submitted as required and the application documents are true. Following the preliminary examination, the Department of Civil Affairs will review the application documents and present them to the Housing Security Bureau to verify.

\subsubsection{Supervision}

It is necessary to establish a supervisory system for housing security. The supervision forms includes letter, phone call and visit. And the scope of the supervision can be involved in applicants of affordable housing, the owners of affordable housing, the personnel who are responsible for the affordable housing application examination, verification and approval.

\subsubsection{Administration}

When the affordable housing application is approved, the applicants will move to their new houses. And the authority will inspect the changes of living conditions of the affordable housing residents once a year. If any household is found not eligible at all and they just access to the affordable housing through fraud, the authority can take it back.

\subsection{Judiciary Remedies for Affordable Housing Distribution}

Substantive law is different from procedural law though they both are the major categories within law. In China, Substantive law stems from legislative statutes rather than judicial decisions in common law system. Generally, substantive law refers to the body of rules including public law like administrative law and criminal law and private law like civil law and tort law. It defines right and duty of the individuals and the collective bodies and determines the nature of the relationship between participants of a relation based on the forms of ownership and the legal status of property and persons. Procedural law in opposite to substantive law is inseparable from each other. Procedural law refers to a legal process which is conducted in the court to determine the right and obligation of parties. Generally, the process involves filing complaints, serving documents on the opposition and conduct of trials.

Therefore, the affordable housing law is the substantive law. The right and obligations have been determined and stipulated in the substantive law. The judiciary is the the process to grant the remedies if the right is violated. Based on the distribution relationship of affordable housing, administrative procedure and criminal procedure might be involved in the wrongdoings. The administrative procedure falls into the jurisdiction when the plaintiff files a complaint against the affordable housing officers. And the criminal procedure falls into the jurisdiction when the crimes are committed in the affordable housing distribution cases.

\subsection{Sanction upon the wrongdoings of affordable housing distribution}

There are two types punishment might happen in affordable housing distribution. One the administrative sanction due to the wrongdoings from the applicant and the wrongdoings from the administrative officers. The other one is criminal sanction due to the crimes committed by the applicant who commits swindle and by the officer who commits bribery and malpractice in affordable housing distribution.

\section{Conclusion}

In China, the government plays a dominant role in building the social security housing. However, the unfair distribution of the affordable housing leads to the negative impact on the security housing policy. This study attempts to justify the rational of theory of justice within the context of affordable housing system to formulate a 
theoretical framework to guide the fair distribution of affordable housing. And the conclusion is that a theory of justice of John Rawls provides not only a rationale for affordable housing system, but a way to accomplish the justice of affordable housing distribution. Under the legal operational framework, law as an effective instrument can ensure the goal of affordable housing policy

\section{References}

Affordable Housing Management Mehods. (2007). Ministry of Construction (Document 258). The Central People's Government of People's Republic of China: Ministry of Finance, Ministry of Development and Reform, Ministry of Inspection, Ministry of Finance, Ministry of National Land and Resources, Bank of China, Bureau of Tax.

Aristotle. (1934). The Nicomachean Ethnics (H. Rackham, Trans.). Leob Classical Library. Cambridge, MA: Harvard University Press. (Original work published 350 BC).

Bodenheimer, E. (1981). Jurisprudence---The Philosophy and Method of Law, Harvard University Press, Cambridge, Massachusetts, London, England.

Chen, J. (2010). Country's wealth divide past warning level. China Daily. [Online] Available: $\mathrm{http} / / \mathrm{www} . c h i n a d a i l y . c o m . c n / c h i n a / 2010-05 / 12 /$ content_983703 htm (May 12, 2010)

Cicero, M. T. (1951). De Finibus Bonorum et Malorum (H. Rackham, Trans). Leob Classical Library. London: Heinemann. (Original work published $45 \mathrm{BC}$ ).

Dorothy, S. (2006). The Creation of a New Underclass in China and its Implications. Environment \& Urbanization, Vol. 18, (1):177-193. doi:10.1177/0956247806063972, http://dx.doi.org/10.1177/0956247806063972

Gabriel, M., Jacobs, K., Arthurson, K. and Burke, T. \& Yates, J. (2005). Conceptualising and Measuring the Housing Affordability Problem, Research Paper 1, National Research Venture 3 'Housing Affordability for Lower Income Australians', AHURI, Melbourne. [Online] Available: http://www.ahuri.edu.au/nrv/nrv3/NRV3_Assoc_docs.html

Haffner, M. A., \& Boumeester, H.J. (2010). The Affordability of Housing in the Netherlands: An Increasing Income Gap Between Renting and Owning? Housing Studies, Vol. 25, No. 6, November, 799-820. doi:10.1080/02673037.2010.511472, http://dx.doi.org/10.1080/02673037.2010.511472

Milligan, V., Phibbs, P., Fagan, K. and Gurran, N. (2004). A Practical Framework for Expanding Affordable Housing Services in Australia: Learning from Experience, Final Report 61, AHURI, Melbourne. [Online] Available: www.qahc.asn.au/images $2 /$ website/practicalfw\%20for\%20ah.pdf

Pound, R. (1923). 'The theory of judicial decision. Harvard Law Review, 36:641-62. [Online] Available: www.princeton.edu/ kewhitt/judicial_review.

Rawls, J. (1999). A theory of justice. (Revised Edition). Cambridge, MA: Harvard University Press.

Yi, N. (2008). The performance and problems of affordable housing policy in China. International Journal of Housing Markets and Analysis, Vol. 1 No. 2, pp. 125-146. doi:10.1108/17538270810877763, http://dx.doi.org/10.1108/17538270810877763 
Table 1. Timetable of Central Government Affordable Housing Policy and Regulations (Source: Author)

\begin{tabular}{|l|l|l|l|l|}
\hline System & Time & $\begin{array}{l}\text { Policy and } \\
\text { Regulation }\end{array}$ & $\begin{array}{l}\text { Legislature and } \\
\text { policy-maker }\end{array}$ & Target \\
\hline $\begin{array}{l}\text { Affordable } \\
\text { Housing } \\
\text { System }\end{array}$ & 1994 & Reform Decision & State council & $\begin{array}{l}\text { Low and middle } \\
\text { income }\end{array}$ \\
\cline { 2 - 6 } & 1994 & $\begin{array}{l}\text { Ways of } \\
\text { Construction } \\
\text { Administration }\end{array}$ & $\begin{array}{l}\text { Construction } \\
\text { Department and } \\
\text { Finance } \\
\text { Department }\end{array}$ & $\begin{array}{l}\text { Low and middle } \\
\text { income with } \\
\text { housing difficulty }\end{array}$ \\
\cline { 2 - 6 } & 1998 & Announcement & State Council & $\begin{array}{l}\text { Low and middle } \\
\text { income }\end{array}$ \\
\cline { 2 - 6 } & 1999 & $\begin{array}{l}\text { Sale } \\
\text { Administration }\end{array}$ & $\begin{array}{l}\text { Construction } \\
\text { Department }\end{array}$ & No prescription \\
\cline { 2 - 5 } & 2004 & $\begin{array}{l}\text { Affordable } \\
\text { Housing } \\
\text { Regulations }\end{array}$ & $\begin{array}{l}\text { Construction } \\
\text { Department and } \\
\text { National } \\
\text { Decelopment } \\
\text { Commission }\end{array}$ & No prescription \\
\cline { 2 - 5 } & 2007 & State Council & $\begin{array}{l}\text { Low and middle } \\
\text { income household } \\
\text { in urban areas }\end{array}$ \\
\cline { 2 - 5 } & 2007 & $\begin{array}{l}\text { Opinoins } \\
\text { Aousing } \\
\text { Regulations }\end{array}$ & $\begin{array}{l}\text { Joint Departments } \\
\text { income household } \\
\text { in urban areas }\end{array}$ \\
\hline
\end{tabular}

Table 2. Floor Space of Commercialized Buildings Sold by Use

(Unit :10 000 sq.m)

$\begin{array}{ll}\text { Year } & \begin{array}{l}\text { Floor Space of } \\ \text { Commercialized }\end{array} \\ \text { Region } & \text { Buildings Sold }\end{array}$

1997

9010.17

1998

12185.30

1999

2000

2001

2002

2003

2004

2005

2006

2007

2008
14556.53

18637.13

22411.90

26808.29

33717.63

38231.64

55486.22

61857.07

77354.72

65969.83

\section{Residential \\ Buildings}

7864.30

10827.10

12997.87

16570.28

19938.75

23702.31

29778.85

33819.89

49587.83

55422.95

70135.88

59280.35
Villas,

High-grade

Apartments

254.25

345.30

435.74

640.72

878.19

1241.26

1449.87

2323.05

2818.44

3672.44

4581.31

2865.25
Economically

Affordable

Housing

1211.85

1666.50

2701.31

3760.07

4021.47

4003.61

4018.87

3261.80

3205.01

3336.97

3507.52

3627.25 
2009

\begin{tabular}{|c|c|c|c|c|}
\hline Beijing & 1335.37 & 1031.43 & 164.53 & 108.32 \\
\hline Tianjin & 1252.04 & 1135.35 & 46.62 & 168.26 \\
\hline Hebei & 2231.84 & 2128.86 & 34.27 & 168.29 \\
\hline Shanxi & 994.71 & 893.10 & 18.57 & 57.92 \\
\hline Inner Mongolia & 2396.37 & 2093.34 & 96.07 & 262.25 \\
\hline Liaoning & 4091.16 & 3731.19 & 130.72 & 137.49 \\
\hline Jilin & 1583.87 & 1435.73 & 67.32 & 72.20 \\
\hline Heilongjiang & 1486.57 & 1286.62 & 25.82 & 74.80 \\
\hline Shanghai & 2339.29 & 2007.48 & 265.54 & \\
\hline Jiangsu & 6091.86 & 5282.89 & 307.05 & 314.25 \\
\hline Zhejiang & 2992.20 & 2480.74 & 159.35 & 153.24 \\
\hline Anhui & 2785.83 & 2542.60 & 34.45 & 55.20 \\
\hline Fujian & 1625.67 & 1250.00 & 62.18 & 83.81 \\
\hline Jiangxi & 1727.60 & 1604.86 & 28.44 & 157.15 \\
\hline Shandong & 5507.64 & 5039.40 & 93.02 & 201.65 \\
\hline Henan & 3191.98 & 2943.36 & 65.55 & 204.55 \\
\hline Hubei & 1941.62 & 1821.31 & 58.54 & 225.38 \\
\hline Hunan & 2655.51 & 2413.70 & 109.57 & 97.35 \\
\hline Guangdong & 4852.28 & 4360.45 & 423.43 & 9.89 \\
\hline Guangxi & 1768.04 & 1637.99 & 47.40 & 47.50 \\
\hline Hainan & 372.44 & 358.72 & 108.23 & 8.23 \\
\hline Chongqing & 2872.19 & 2669.93 & 117.38 & 332.79 \\
\hline Sichuan & 3501.27 & 3247.32 & 96.87 & 39.92 \\
\hline Guizhou & 908.20 & 848.11 & 13.10 & 135.04 \\
\hline Yunnan & 1643.08 & 1478.25 & 186.29 & 104.81 \\
\hline Tibet & 66.49 & 62.08 & 16.28 & 7.55 \\
\hline Shanxi & 1513.01 & 1426.06 & 38.85 & 150.13 \\
\hline Gansu & 624.66 & 588.63 & 0.65 & 93.26 \\
\hline Qinghai & 147.89 & 141.23 & 7.87 & 1.17 \\
\hline Ningxia & 514.81 & 453.26 & 8.09 & 20.85 \\
\hline Xinjiang & 954.35 & 886.35 & 33.21 & 134.01 \\
\hline
\end{tabular}




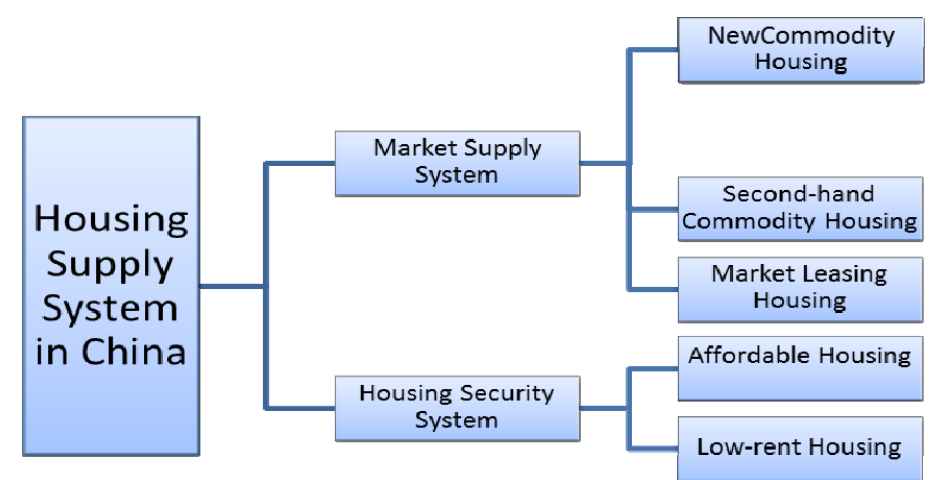

Figure 1. Housing Supply System in China

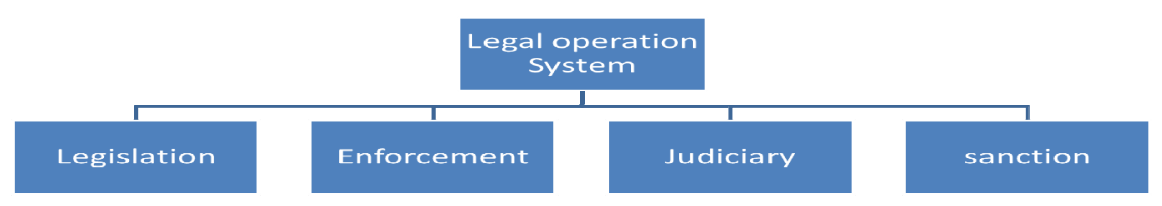

Figure 2. Conceptual Framework of Legal Operational System

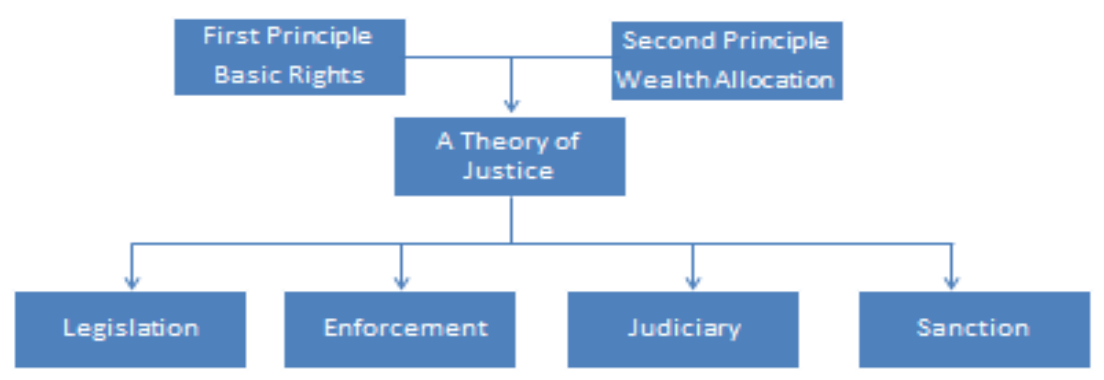

Figure 3. Theoretical Framework of A Theory of Justice

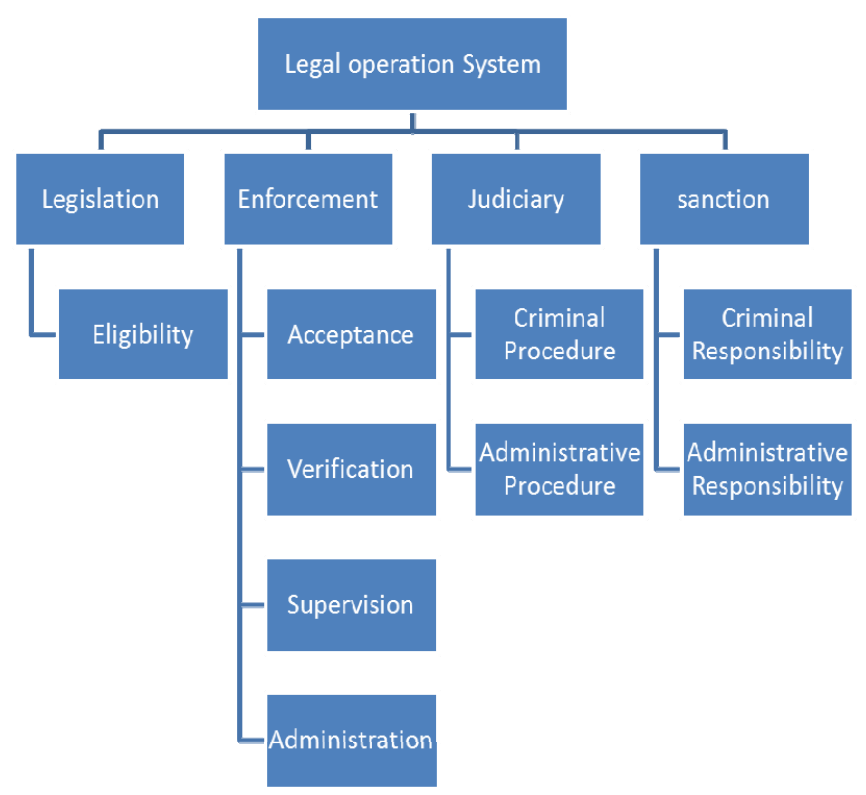

Figure 4. Conceptual framework of affordable housing distribution 